\title{
Kerentanan Anak Indonesia terhadap Kekerasan Seksual Online Era Covid-19: Sebuah Perspektif Hukum
}

\author{
Nadira Tatyana \\ Fakultas Hukum, Universitas Gadjah Mada, Yogyakarta \\ "Penulis Koresponden: nadira.tatyana@mail.ugm.ac.id
}

\section{ABSTRAK}

Sejak terjadinya pandemi COVID-19, kekerasan seksual online anak di Indonesia meningkat seiring dengan meningkatnya paparan terhadap internet dan teknologi digital, sehingga berakibat buruk bagi berkembangan anak. Penelitian ini bertujuan untuk mengetahui pengaruh COVID-19 terhadap kekerasan seksual anak serta pengaturan dan perlindungan hukum atas kekerasan seksual online anak. Penelitian ini termasuk penelitian yuridis normatif dan menggunakan data sekunder. Analisis data menggunakan metode kualitatif dengan menganalisis dokumen dari data sekunder, sehingga bersifat deskriptif-analitis yang menggambarkan suatu gejala sosial. Penelitian ini menghasilkan dua kesimpulan. Pertama, COVID-19 berpengaruh terhadap kenaikan tingkat kekerasan seksual online terhadap anak dikarenakan tingginya paparan internet dan teknologi digital terhadap anak. Kedua, pemerintah telah meratifikasi Convention on the Rights of the Child dan optional protocol terkait serta Undang-Undang Perlindungan Anak. Hal yang perlu dikritisi antara lain peningkatan pengawasan orang tua atas aktivitas berinternet anak dan penegakkan hukum dalam Undang-Undang Perlindungan Anak.

Kata Kunci: Kekerasan Seksual Online Anak; Perlindungan Anak; Hak atas Anak; COVID-19

\section{ABSTRACT}

Ever since COVID-19 hit, the rate of online sexual violence against child in Indonesia has risen tremendously along with the increasing exposure to the internet and digital technology, hence would adversely affect child development. This research aims to find the impacts of COVID-19 towards online sexual violence against child as well as regulations and legal protections of online sexual violence against child. This research is normative juridical research. This research uses secondary data. The data analysis used in this research is qualitative method by analyzing collected secondary data, therefore this research is descriptive-analytical which explains a social phenomenon. There are two conclusions in this research. First, COVID-19 impacts the rising rate of online sexual violence against child due to the high exposure of internet and digital technology usage. Second, government has ratified Convention on the Rights of the Child and its related optional protocol and Child Protection Law. There are criticized matters regarding this research, inter alia strengthening parents'surveillance on child's internet activities and the law enforcement on Child Protection Law.

Kata Kunci: Online Sexual Violence against Child; Child Protection; Rights of the Child; COVID-19

\section{PENDAHULUAN}

Kemunculan pandemi COVID-19, penyakit yang mewabah disebabkan oleh virus SARS-CoV-2 dan menyerang sistem pernapasan manusia, telah mempengaruhi berbagai aspek kehidupan manusia. Kasus pertama COVID-19 teridentifikasi di Kota Wuhan, Tiongkok pada bulan Desember 2019. Beberapa orang yang terjangkit COVID-19 di Wuhan merupakan orang yang 
lekat beraktivitas di pasar tradisional, sehingga pemerintah setempat menutup pasar tradisional setempat untuk memperlambat laju penyebaran. ${ }^{1}$

Sebelumnya pada tahun 2003, telah terjadi wabah yang disebabkan oleh virus SARS-CoV-1 yang memiliki hubungan genetis erat dengan kelelawar. Sumber SARS-CoV-2 juga erat kaitannya bersumber dari hewan, meskipun World Health Organization (WHO) belum mengidentifikasi apakah bersumber dari hewan jinak, hewan liar, atau hewan liar yang dijinakkan. Semenjak kemunculan kasus pertama di Wuhan pada tahun 2019 silam, COVID-19 telah menyebar secara global. $^{2}$

Tercatat kasus COVID-19 pertama di Indonesia dilaporkan oleh Presiden Joko Widodo pada tanggal 2 Maret 2020. Diketahui bahwa kasus tersebut diakibatkan oleh kontak erat dengan WN Jepang yang terinfeksi penyakit serupa. ${ }^{3}$ Setelah kasus domestik pertama tersebut, pemerintah khsusnya DKI Jakarta mulai menerapkan restriksi terhadap car-free day, kegiatan belajar mengajar di sekolah, kegiatan ibadah di tempat-tempat ibadah, hingga Pembatasan Sosial Berskala Besar (PSBB) pada bulan April. ${ }^{4}$

Pandemi COVID-19 secara masif telah mendisrupsi berbagai sektor usaha dan aspek kehidupan di berbagai wilayah, terutama secara ekonomi. Kebijakan pembatasan sosial dan anjuran karantina mandiri mempengaruhi turunnya kegiatan sektor pariwisata, transportasi, dan sektor-sektor usaha lainnya. ${ }^{5}$ Dalam hal kesejahteraan dan kesehatan mental manusia, COVID-19 mempengaruhi kesehatan manusia akibat dampak langsung yang ditimbulkan penyakit tersebut dan dampak atas isolasi diri, ketakutan atas kehilangan orang terkasih, bahkan ketakutan atas kematian akibat kelaparan. ${ }^{6}$

Menurut Beland dkk., terdapat dampak jangka pendek COVID-19 terhadap ketenagakerjaan dan pengupahan. COVID-19 meningkatkan tingkat pengangguran, pengurangan jam kerja dan minimnya pengaruh partisipasi angkatan kerja terhadap pengupahan. Lebih lanjut, Pouliakas dan Branka serta Fana dkk. berpendapat bahwa sektor tenaga kerja yang kemungkinan besar terdampak dari pembatasan sosial akibat COVID-19 adalah kelompok-kelompok rentan, antara lain perempuan, migran, orang-orang dengan perjanjian kerja non-standar (wiraswasta dan pekerja

\footnotetext{
${ }^{1}$ World Health Organization, Coronavirus disease 2019 (COVID-19) Situation Report - 94, https://www.who.int/docs/default-source/coronaviruse/situation-reports/20200423-sitrep-94-covid-19.pdf, diakses pada tanggal 26 Maret 2021.

${ }^{2}$ Ibid.

${ }^{3}$ Ratna Nuraini, Kasus Covid-19 Pertama, Masyarakat Jangan Panik, https://indonesia.go.id/narasi/indonesia-dalamangka/ekonomi/kasus-covid-19-pertama-masyarakat-jangan-panik, diakses pada tanggal 29 Maret 2021.

${ }^{4}$ Aditya Gagat Hanggara, Jakarta Response to COVID-19 Outbreak: A Timeline, https://corona.jakarta.go.id/en/artikel/linimasa-kebijakan-penanganan-pandemi-covid-19-di-jakarta, diakses pada tanggal 29 Maret 2021.

${ }^{5}$ Association of Southeast Asian Nations, Economic Impact of COVID-19 Outbreak on ASEAN, Asean Policy Brief, April 2020, hlm. 3-4.

${ }^{6}$ Alak Paul dkk., Psychological and Livelihood Impacts of COVID-19 on Bangladeshi Lower Income People, Asia Pacific Journal of Public Health, Vol. 33, No. 1, 2021, hlm. 101-107, DOI: https://doi.org/10.1177/1010539520977304.
} 
sementara), pekerja berpendidikan rendah, pekerja di usaha mikro atau kecil, dan pekerja dengan upah rendah. ${ }^{7}$

Di samping itu, terdapat perubahan dalam penggunaan teknologi di berbagai sektor di Indonesia. iPrice melaporkan adanya perubahan gaya berbelanja, terjadi peningkatan belanja online yang mendorong naiknya angka penjualan di berbagai e-commerce. Dalam konteks pendidikan, kegiatan belajar mengajar yang semula secara tatap muka menjadi jarak jauh melalui teleconference dan menggunakan media berbasis video. Hal ini membuka peluang kepada industri teknologi pendidikan dalam menyediakan pendidikan yang berkualitas dan aksesibel untuk memenuhi permintaan selama pandemi. ${ }^{8}$

Selain itu, terjadi peningkatan dalam kasus kekerasan perempuan. LBH Apik melaporkan bahwa terdapat 1.178 kasus kekerasan berbasis gender yang masuk pada tahun 2020. Angka tersebut meningkat drastis dibandingkan pada tahun 2018 (837 kasus) dan 2019 (794 kasus). Kasus pertama terbanyak adalah kekerasan dalam rumah tangga (KDRT) dan kemudian disusul dengan kekerasan berbasis gender online (KBGO). Kasus KBGO tersebut termasuk ancaman distribusi (112 kasus), konten illegal (66 kasus), upaya memperdaya korban (33 kasus), pelecehan online (47 kasus), pencemaran nama baik (15 kasus), pelanggaran privasi (2 kasus), penguntitan online (17 kasus) dan pengelabuan (1 kasus). ${ }^{9}$

Berbicara mengenai kasus kekerasan seksual terhadap anak, berdasarkan data Sistem Informasi Online Perlindungan Perempuan dan Anak (SIMFONI PPA) bulan Januari hingga Juni 2020, tercatat sebanyak 1.962 anak di Indonesia menjadi korban kekerasan seksual, eksploitasi, dan perdagangan orang. Angka tersebut menunjukkan bahwa anak-anak rentan menjadi korban di situasi bencana. Asisten Deputi Bidang Perlindungan Anak dari Kekerasan dan Eksploitasi, Valentina Gintings, berpendapat bahwa anak kerap mengalami eksploitasi secara ekonomi. ${ }^{10}$

Menurut UNICEF, faktor utama yang menyebabkan meningkatnya angka kekerasan terhadap anak adalah kebijakan pembatasan sosial yang berkaitan dengan disrupsi sektor formal dan informal sebagai sistem yang melindungi anak-anak dari risiko kekerasan. Salah satu faktor umum yang menyebabkan kekerasan terhadap anak adalah meningkatnya penggunaan internet oleh anak yang

\footnotetext{
${ }^{7}$ Marta Fana dkk., Employment Impact of Covid-19 Crisis: from Short Term Effects to Long Term Prospects, Journal of Industrial and Business Economics, Vol. 47, 2020, hlm. 392, DOI: https://doi.org/10.1007/s40812-02000168-5.

${ }^{8}$ Caroline Chan, How COVID-19 is Accelerating Indonesia's Digital Transformation, https:/digital.australiaindonesiacentre.org/news/insights/commentary/how-covid-19-is-accelerating-indonesiasdigital-transformation/, diakses pada tanggal 31 Maret 2021.

${ }^{9}$ CNN Indonesia, 1.178 Kasus Kekerasan Perempuan Terjadi Selama 2020, https://www.cnnindonesia.com/gayahidup/20210107203520-284-590941/1178-kasus-kekerasan-perempuan-terjadi-selama-2020, diakses pada tanggal 31 Maret 2021.

${ }^{10}$ Risna Halidi dan Dini Afrianti Efendi, Selama Pandemi Corona, Hampir 2 Ribu Anak Indonesia Alami Kekerasan Seksual, https://www.suara.com/health/2020/07/08/083741/selama-pandemi-corona-hampir-2-ribu-anakindonesia-alami-kekerasan-seksual?page=all, diakses pada tanggal 31 Maret 2021.
} 
disertai menurunnya pengawasan orang tua, sehingga anak terpapar risiko yang lebih tinggi dari penggunaan internet. ${ }^{11}$

Perlindungan anak diatur secara khusus dalam UU No. 23 Tahun 2002 tentang Perlindungan Anak jo. UU No. 35 Tahun 2014 tentang Perubahan Pertama atas UU Perlindungan Anak jo. UU No. 17 Tahun 2016 tentang Perubahan Kedua atas UU Perlindungan Anak. Pasal 4 UU No. 23 Tahun 2002 mengatur bahwa setiap anak berhak untuk dapat hidup, tumbuh, berkembang, dan berpartisipasi secara wajar sesuai dengan harkat dan martabat kemanusiaan, serta mendapat perlindungan dari kekerasan dan diskriminasi. Anak korban kekerasan juga mendapat perlindungan khusus dari Pemerintah, Pemerintah Daerah, dan lembaga negara lainnya yang berkewajiban dan bertanggung jawab untuk memberikan perlindungan (Pasal 59 ayat (1) dan ayat (2) UU No. 35 Tahun 2014).

Berdasarkan uraian latar belakang di atas, timbul masalah dari penulisan ini yaitu: (1) Bagaimana pengaruh COVID-19 terhadap kerentanan kekerasan seksual online pada anak di Indonesia? dan (2) Bagaimana pengaturan dan perlindungan hukum terhadap kekerasan seksual online terhadap anak di Indonesia?

Adapun dalam penelitian ini, terdapat dua tujuan yang hendak dicapai, yaitu untuk mengetahui pengaruh COVID-19 terhadap kerentanan kekerasan seksual online pada anak di Indonesia dan untuk mengetahui pengaturan dan perlindungan hukum terhadap kekerasan seksual online terhadap anak di Indonesia.

\section{TINJAUAN PUSTAKA}

\section{Kekerasan Seksual terhadap Anak}

Di tahun 1999, World Health Organization (WHO) Consultation on Child Abuse Prevention mendefinisikan bahwa kekerasan terhadap anak termasuk penganiayaan fisik dan/atau batin, kekerasan seksual, penelantaran atau komersialisasi atau eksploitasi lainnya, yang berpotensi membahayakan kesehatan, keberlangsungan hidup, perkembangan atau martabat anak yang berhubungan dengan tanggung jawab, kepercayaan atau kekuatan. Bentuk-bentuk kekerasan tersebut dapat bersifat fatal yang dapat menyebabkan kematian dan non-fatal. ${ }^{12}$

Lebih lanjut, kekerasan seksual terhadap anak didefinisikan sebagai pelibatan seorang anak ke dalam aktivitas seksual yang tidak dipahami sepenuhnya, tidak bisa memberikan penjelasan dan persetujuan, atau belum siap dan tidak bisa memberikan persetujuan, atau melanggar hukum dan

\footnotetext{
${ }^{11}$ The Alliance for Child Protection in Humanitarian Action, End Violence Against Children, United Nations Children's Fund, World Health Organization, COVID-19: Protecting Children from Violence, Abuse and Neglect in the Home, Version 1, Mei 2020, https://www.unicef.org/media/68711/file/COVID-19-Protecting-children-fromviolence-abuse-and-neglect, diakses pada tanggal 1 April 2021.

${ }^{12}$ Desmond Runyan dkk., 2002, Child Abuse and Neglect by Parents and Other Caregivers (From World Report on Violence and Health), World Health Organization, Geneva, hlm. 59-60, https://www.who.int/violence_injury_prevention/violence/global_campaign/en/chap3.pdf, diakses pada tanggal 1 April 2021.
} 
normal sosial yang berlaku. Kekerasan seksual terhadap anak dibuktikan dengan aktivitas antara anak dengan orang dewasa atau anak lainnya yang belum memiliki tanggung jawab, kepercayaan atau kekuatan, yang mana aktivitas tersebut dimaksudkan untuk memuaskan kebutuhan seksual orang lain. ${ }^{13}$

Meskipun anak secara umum termasuk ke dalam kelompok rentan, anak perempuan lebih berisiko dibandingkan anak laki-laki terhadap kekerasan seksual dan pemerkosaan paksa. Penemuan beberapa studi internasional menunjukan angka kekerasan seksual anak perempuan 1,5 - 3 kali lebih tinggi dibandingkan anak laki-laki. Secara global, lebih dari 130 juta anak berusia $6-11$ tahun tidak bersekolah, 60\% dari angka tersebut adalah anak perempuan. Di beberapa negara, anak perempuan tidak diizinkan untuk mengenyam pendidikan, melakukan pekerjaan domestik, atau bekerja untuk membantu kondisi ekonomi keluarga. ${ }^{14}$

Anak laki-laki cenderung lebih berisiko terhadap hukuman fisik di banyak negara. Walaupun anak perempuan lebih berisiko terhadap pembunuhan anak di berbagai tempat, masih belum jelas alasan mengapa anak laki-laki mendapatkan hukuman fisik yang lebih kasar. Hal tersebut mungkin berkaitan dengan kedewasaan dan rasa tanggung jawab seseorang, sehingga laki-laki cenderung lebih mendapatkan hukuman fisik. Cukup jelas bahwa terdapat perbedaan budaya yang berperan besar dalam membentuk peran dan nilai-nilai berdasarkan gender. ${ }^{15}$

United Nations (UN) membentuk Convention on the Rights of the Child (CRC) yang berlaku secara hukum pada tahun 1990. Pasal 34 CRC menegaskan bahwa para negara penandatangan berupaya melindungi anak dari segala bentuk eksploitasi seksual dan kekerasan seksual dengan mengambil langkah-langkah dalam lingkup nasional, bilateral, dan multilateral untuk menghindari bujukan atau pemaksaan anak untuk melakukan aktivitas seksual yang melanggar hukum, mengeksploitasi anak dengan cara prostitusi atau cara-cara lainnya yang melanggar hukum, serta mengeksploitasi anak dalam hal pornografi ${ }^{16}$

\section{METODOLOGI PENELITIAN}

Jenis penulisan ini adalah penelitian hukum. Menurut Soerjano Soekanto, penelitian hukum merupakan suatu kegiatan ilmiah yang didasarkan pada metode, sistematika dan pemikiran tertentu yang bertujuan untuk mempelajari satu atau beberapa gejala hukum tertentu dengan analisanya. ${ }^{17}$ Penelitian ini bersifat yuridis normatif yang menggunakan kepustakaan dengan cara menelaah

\footnotetext{
${ }^{13}$ World Health Organization, Violence Injury Prevention, https://www.who.int/violence_injury_prevention/resources/publications/en/guidelines_chap7.pdf, diakses pada tanggal 1 April 2021.

${ }^{14}$ Desmond Runyan dkk., op. cit., hlm. 66.

15 Ibid.

16 Soerjono Soekanto, 2014, Pengantar Penelitian Hukum, Universitas Indonesia (UI-Press), Jakarta, hlm. 43.

${ }^{17}$ Soerjono Soekanto, 2014, Pengantar Penelitian Hukum, Universitas Indonesia (UI-Press), Jakarta, hlm. 43.
} 
sistematika peraturan perundang-undangan dan menelaah taraf sinkronisasi dari peraturan perundang-undangan. ${ }^{18}$

Dilihat dari jenisnya, penelitian ini bersifat deskriptif analitis, yang mana memberikan data seteliti mungkin tentang manusia dan gejala-gejala lainnya dengan menganalisis identifikasi masalah. ${ }^{19}$ Data yang digunakan dalam penelitian ini berupa data sekunder. Data sekunder terdiri atas: (i) bahan hukum primer yang bersifat mengikat antara lain konvensi dan peraturan perundangundangan, (ii) bahan hukum sekunder yang memberikan penjelasan mengenai bahan hukum primer antara lain buku, jurnal, laporan dan karya tulis lainnya yang berhubungan dengan kekerasan seksual online pada anak di Indonesia dan pandemi COVID-19. ${ }^{20}$

Analisis data dilakukan dengan metode kualitatif. Metode ini dipilih karena penelitian ini bersifat deskriptif-analitis dengan mempelajari gejala sosial yang ada. Metode kualitatif menggunakan data yang diambil melalui wawancara, observasi lapangan, atau dokumen yang ada. Dalam konteks penelitian ini, Penulis menggunakan dokumen yang berupa data sekunder. ${ }^{21}$

\section{HASIL DAN PEMBAHASAN}

Pengaruh COVID-19 terhadap Kerentanan Kekerasan Seksual Online pada Anak di Indonesia

Berbicara tentang kelompok rentan, anak termasuk kedalam kelompok rentan, namun perlu dipahami terlebih dahulu apa yang dimaksud dengan kerentanan (vulnerability). Kerentanan biasanya diartikan sebagai ketidakmampuan seseorang untuk melindungi kepentingannya secara utuh dan mandiri. Individu atau kelompok yang tergolong rentan disebabkan oleh kurangnya atau terganggunya kapasitas untuk memberikan penjelasan dan persetujuan atau karena keadaan seperti penyakit akut atau kondisi ekonomi yang buruk, sehingga berisiko untuk dieksploitasi atau diperlakukan tidak adil. ${ }^{22}$

UN membuat CRC yang bermaksud untuk mempertegas prinsip-prinsip hak asasi manusia dalam Universal Declaration of Human Rights dan Convenant on Human Rights. Anak akan tumbuh dalam masyarakat dan harus mengemban tanggung jawabnya dalam masyarakat, sehingga keluarga dianggap berperan penting untuk melindungi anak dan mendukung tumbuh kembangnya. Sebab dalam Declaration of the Rights of the Child, anak-anak secara psikis dan mental belum dewasa dan membutuhkan perlindungan khusus, termasuk perlindungan hukum sebelum dan sesudah lahir. ${ }^{23}$

\footnotetext{
${ }^{18}$ Soerjono Soekanto dan Sri Mamudji, 1994, Penelitian Hukum Normatif: Suatu Tinjauan Singkat, Raja Grafindo Persada, Jakarta, hlm. 14.

${ }^{19}$ Soerjono Soekanto, op cit., hlm. 9-10.

${ }^{20} \mathrm{Ibid}$, hlm. 51-52.

${ }^{21}$ J. R. Raco, 2010, Metode Penelitian Kualitatif: Jenis, Karakteristik dan Keunggulannya, Grasindo, Jakarta, hlm. 67.

${ }^{22}$ Presidential Commission for the Study of Bioethical Issues, Vulnerable Populations: Safeguarding Children, https://bioethicsarchive.georgetown.edu/pcsbi/sites/default/files/6\%20Vulnerable\%20Populations\%20Safeguardin g\%20Children\%209.30.16.pdf, diakses pada tanggal 3 April 2021.

${ }^{23}$ See preamble of UNCRC.
} 
Masa kanak-kanak dapat dikatakan sebagai masa paling rentan dalam masa hidup manusia. Anak sangat bergantung kepada orang lain untuk memenuhi kebutuhan dasarnya, yang mana menjadikannya rentan. Meskipun secara umum lansia tidak dapat mengurus dirinya sendiri, lansia dapat memilih siapa yang mengurus mereka dan bahkan sebagian lansia dapat mengurus dirinya sendiri. Tidak demikian dengan anak, anak tidak berada dalam posisi memiliki otonomi penuh untuk membuat pilihannya sendiri. Anak sangat bergantung pada keputusan orang lain sejak sebelum dan sesudah mereka lahir. ${ }^{24}$

Kekerasan seksual terhadap anak merupakan masalah global yang memerlukan penanganan yang komprehensif. Istilah kekerasan seksual terhadap anak mencakup beragam tindakan kekerasan dalam kondisi dan hubungan yang berbeda, antara lain ketika anak menjadi korban kekerasan seksual oleh anggota keluarganya atau walinya, perkosaan oleh pasangan, memojokkan anak pada posisi membarter seks untuk makanan, kekerasan seksual terhadap anak yang dilakukan oleh orang yang memiliki kuasa, atau pencabulan dan eksploitasi seksual online oleh anak atau orang dewasa lainnya. $^{25}$

UNICEF menjabarkan bahwa kekerasan seksual terhadap anak termasuk kekerasan berbasis gender. Meskipun perempuan juga menjadi pelaku kekerasan seksual terhadap anak dan remaja, namun 90\% dari pelaku adalah laki-laki. Laporan menunjukkan bahwa kekerasan seksual terhadap anak perempuan 2 - 3 kali lebih tinggi dibandingkan anak laki-laki, meskipun di beberapa negara dan organisasi tertentu angka terhadap anak laki-laki lebih tinggi. ${ }^{26}$ Desmond Runyan dkk. juga menegaskan bahwa meskipun anak secara umum termasuk kelompok rentan, anak perempuan lebih berisiko 1,5 - 3 kali lebih tinggi terhadap kekerasan seksual dibandingkan anak laki-laki. ${ }^{27}$

Dalam dua dekade terakhir terjadi peningkatan tajam dan serapan teknologi digital secara global, yang mana turut memperkenalkan bentuk-bentuk baru dari bahaya teknologi digital dalam kekerasan seksual terhadap anak baik secara online maupun tidak. Kasus pencabulan online anak (online child grooming), live streaming kekerasan seksual anak di internet, dan penyebaran konten kekerasan seksual anak meningkat secara signifikan. Konten kekerasan seksual anak yang beredar di internet maupun hidden web telah mencapai jumlah jutaan. ${ }^{28}$

Sebetulnya teknologi digital tidak menyebabkan kekerasan seksual online anak, melainkan memfasilitasi kekerasan seksual online anak lebih besar lagi. Konten kekerasan seksual online anak adalah bukti kekerasan seksual anak secara langsung, biasanya pelaku adalah orang yang

\footnotetext{
${ }^{24}$ Alexander Bagattini, Children's Well-being and Vulnerability, Ethics and Social Welfare, Vol. 13, No. 3, Agustus, 2019, DOI: https://doi.org/10.1080/17496535.2019.1647973.

${ }^{25}$ United Nations Children's Fund, 2020, Action to End Child Sexual Abuse and Exploitation, UNICEF Child Protection Section Programme Division 3 United Nations Plaza New York, New York, hlm. 5., https://www.unicef.org/media/89206/file/CSAE-Brief-v3.pdf, diakses pada tanggal 3 April 2021.

26 Ibid, hlm. 6.

${ }^{27}$ Desmond Runyan dkk., 2002, Child Abuse and Neglect by Parents and Other Caregivers (From World Report on Violence and Health), World Health Organization, Geneva, hlm. 66, https://www.who.int/violence_injury_prevention/violence/global_campaign/en/chap3.pdf, diakses pada tanggal 3 April 2021.

${ }^{28}$ United Nations Children's Fund, op cit., hlm. 4.
} 
memiliki hubungan dekat dengan anak. Sifat kekerasan seksual online anak itu sendiri membutuhkan kolaborasi antara teknologi dengan penegakan hukum antarwilayah. Lebih lanjut, dibutuhkan pemahaman mendalam bagaimana anak dan keluarganya menggunakan teknologi digital beserta riwayatnya. ${ }^{29}$

End Child Prostitution and Trafficking (ECPAT) Indonesia melakukan pemetaan terhadap situasi kerentanan anak dan eksploitasi seksual online dengan menelaah kuisioner online kepada 1.203 responden dengan rentang usia 6 hingga 17 tahun. Ditemukan peningkatan penggunaan internet anak sebesar 67\% dibandingkan sebelum COVID-19. Bahkan, sebagian besar responden mengaku menghabiskan lebih dari enam jam dalam sehari menggunakan internet. Hal ini menunjukan bahwa aktivitas anak-anak yang tinggi dalam menggunakan internet menjadikan anak-anak rentan terhadap eksploitasi seksual online. ${ }^{30}$

Dari 1.203 responden tersebut, ditemukan sejumlah 287 pengalaman buruk anak saat berinternet selama COVID-19. Bentuk-bentuk pengalaman tersebut antara lain dikirimkannya pesan teks yang tidak sopan dan senonoh (112 responden), dikirimkannya gambar atau video yang membuat tidak nyaman (66 responden), hingga dikirimi gambar atau video yang menampilkan pornografi (27 responden). Sebagian besar responden tidak memilih untuk menceritakan pengalaman buruk tersebut kepada orang terdekat. ${ }^{31}$

UNICEF menjelaskan bahwa anak yang mengalami kekerasan seksual pada umumnya dan kekerasan seksual online pada khususnya, tidak selalu menyadari bahwa tindakan tersebut termasuk kekerasan seksual. Dampak dari kekerasan seksual online anak beragam, bergantung pada tingkat keparahan dan durasi kekerasan tersebut, perkembangan anak dalam memahami tindakan kekerasan seksual, dan cara keluarga, teman, masyarakat mengatasi kekerasan seksual tersebut. $^{32}$

Kekerasan seksual online terhadap anak berdampak secara fisik dan psikis, seperti memiliki kecenderungan tinggi terjangkit virus HIV akibat aktivitas seksual yang tidak aman; penggunaan alkohol dan obat-obatan terlarang; mengalami gangguan kecemasan, depresi, trauma psikologis dan tindakan menyakiti diri sendiri (self-harm); dan meninggalkan sekolah sehingga hanya mendapatkan pendidikan rendah. Selanjutnya, anak yang menjadi korban kekerasan seksual online juga berisiko mengalami bentuk kekerasan seksual online lain dari orang dewasa atau di dalam kondisi lainnya. ${ }^{33}$

Karena keluarga dan orang terdekat anak memiliki kuasa dan pengaruh yang besar terhadap anak, maka dapat ditempuh beberapa cara untuk menghindari kekerasan seksual online anak. Pertama,

${ }^{29}$ Ibid.

30 Deden Ramadani, Kekerasan Seksual Anak Online di Masa Pandemi COVID-19 Meningkat, https://ecpatindonesia.org/en/berita/kekerasan-seksual-anak-online-meningkat-di-masa-pandemi-covid-19/, diakses pada tanggal 3 April 2021.

${ }^{31}$ Ibid.

${ }^{32}$ United Nations Children's Fund, op cit., hlm. 8.

${ }^{33}$ Ibid. 
menutup akses terhadap suatu alamat situs tertentu dengan metode penapisan (filtering). Penapisan umumnya dilakukan oleh penyedia jasa internet mlalui prosedur tertentu dan pemerintah juga aktif memblokir situr-situs yang tidak boleh diakses berdasarkan peraturan perundang-undangan. ${ }^{34}$

Kedua, orang tua dapat mengatur mode restriksi untuk aplikasi Youtube dan mengaktifkan "Google Safe Search" yang dapat menapis konten-konten eksplisit seperti pornografi. Namun perlu diingat bahwa mode restriksi tersebut tidak 100\% menyaring seluruh konten negatif, namun tetap membatasi akses terhadap konten negatif. Ketiga, aktif melaporkan konten negatif ke Kementerian Komunikasi dan Informasi (Kemenkominfo). Pelaporan konten negatif ke Kemenkominfo kemudian akan ditindaklanjuti untuk ditelaah apakah melanggar undang-undang dan dapat dilakukan pemblokiran atau tidak. ${ }^{35}$

Pengaturan dan Perlindungan Hukum terhadap Kekerasan Seksual Online terhadap Anak di Indonesia

Sebagaimana dijelaskan pada pembahasan pertama, UN membentuk CRC yang mulai berlaku secara hukum pada tahun 1990. Indonesia melalui Keppres No. 36 Tahun 1990 meratifikasi CRC. Dalam konsideransnya, Indonesia meratifikasi CRC karena anak merupakan cikal bakal sumber daya bangsa sehingga perlu diberikan pembinaan karena kesejahteraan anak selain menjadi tanggung jawab orang tua dan keluarga, juga menjadi tanggung jawab pemerintah.

Selanjutnya, pemerintah juga membentuk UU No. 23 Tahun 2002 tentang Perlindungan Anak (UU Perlindungan Anak) yang telah diubah dengan UU No. 35 Tahun 2014 tentang Perlindungan dan diubah lagi dengan UU No. 17 Tahun 2016 untuk melindungi hak-hak anak. Sesuai dengan Pasal 1 CRC, 'Anak' dalam UU No. 35 Tahun 2014 tentang Perubahan Pertama atas UU Perlindungan Anak didefinisikan sebagai seseorang yang belum berusia 18 tahun, termasuk anak yang masih dalam kandungan. Umumnya dalam Undang-Undang tersebut anak berhak atas perlindungan dari segi ekonomi, sosial, budaya, dan kesehatan. Perlindungan tersebut harus terintegrasi dengan seluruh pihak, termasuk pemerintah, masyarakat, keluarga dan orang tua.

Pasal 15 menegaskan bahwa setiap anak berhak memperoleh perlindungan dari kejahatan seksual. Pasal 59 Undang-Undang tersebut menegaskan bahwa pemerintah, pemerintah daerah, dan lembaga negara lainnya wajib memberikan perlindungan khusus yang diantaranya untuk anak yang dieksploitasi secara ekonomi dan/atau seksual, korban pornografi, korban perdangangan manusia, dan korban kejahatan seksual. Perlindungan khusus bagi anak yang dieksploitasi secara ekonomi dan/atau seksual ditempuh melalui penyebarluasan dan/atau sosialisasi ketentuan peraturan perundang-undangan yang berkaitan dengan eksploitasi ekonomi dan/atau seksual anak, penegakan dan proses hukum, serta melibatkan masyarakat untuk mengatasi tindakan tersebut. ${ }^{36}$

\footnotetext{
${ }^{34}$ Ahmad Sofian dkk., 2018, Modul Pelatihan Pencegahan Eksploitasi Seksual Anak Online untuk Organisasi Perlindungan Anak dan Komunitas, P. ECPAT Indonesia, Jakarta, hlm. 47, http://eksis.ditpsmk.net/uploads/book/file/186F5A7E-E5E5-416C-9B00-A7BB88101526/moduleksploitasifinal180207071018.pdf, diakses tanggal 3 April 2021.

${ }^{35}$ Ibid, hlm. 52-56.

${ }^{36}$ Lihat Pasal 66 UU No. 35 Tahun 2014 tentang Perubahan atas UU No. 23 Tahun 2002 tentang Perlindungan Anak.
} 
Untuk anak yang menjadi korban pornografi, perlindungan khususnya melalui upaya pembinaan, pendampingan, serta pemulihan sosial, kesehatan fisik dan mental. Untuk anak yang menjadi korban perdagangan, perlindungan khususnya ditempuh dengan upaya pengawasan, perlindungan, pencegahan, perawatan dan rehabilitasi. Kemudian, anak korban kejahatan seksual mendapatkan perlindungan khusus melalui edukasi tentang kesehatan reproduksi, nilai agaman dan kesusilaan; rehabilitasi sosial; pendampingan psikososial; serta pendampingan dan perlindungan di sistem peradilan. ${ }^{37}$

Berbicara tentang UU Perlindungan Anak itu sendiri, UU Perlindungan Anak dibuat setelah diratifikasinya CRC pada tahun 1990 dan meskipun memasukkan konvensi tersebut ke dalam sistem hukum nasional Indonesia, ketentuannya tetap disesuaikan dengan UUD 1945. Kemudian pada tahun 2014 dibentuklah Undang-Undang yang mengubah UU Perlindungan Anak. Ketentuannya lebih komprehensif dibandingkan Undang-Undang sebelumnya dan memasukkan ketentuan mengenai kekerasan seksual (eksploitasi seksual anak, pornografi, perdagangan anak, dan kejahatan seksual).

Berdasarkan pengamatan penulis, UU No. 35 Tahun 2014 mengatur perlindungan anak secara lebih komprehensif karena dibuat setelah meratifikasi Optional Protocol to the Convention on the Rights of the Child on the Sale of Children, Child Prostitution and Child Pornography melalui UU No. 10 Tahun 2012. Protokol tersebut secara garis besar membahas langkah-langkah yang dapat diambil pemerintah untuk mengatasi kekerasan seksual anak, meskipun tidak menegaskan secara eksplisit mengenai tindakan tersebut dilakukan secara online atau tidak.

Tindak pidana kekerasan seksual anak diatur dalam UU No. 35 Tahun 2014 dan UU No. 17 Tahun 2016 yang mengesahkan Perppu No. 1 Tahun 2016 tentang Perubahan Kedua atas UU Perlindungan Anak. Bagi setiap orang yang melakukan persetubuhan paksa terhadap anak diancam dengan pidana penjara paling singkat 5 tahun dan paling lama 15 tahun serta denda paling banyak 5 miliar rupiah. ${ }^{38}$ Untuk orang yang melakukan kekerasan atau ancaman kekerasan untuk melakukan perbuatan cabul, maka diancam dengan pidana penjara paling singkat 5 tahun dan paling lama 15 tahun serta denda paling banyak 5 miliar rupiah. ${ }^{39}$

Orang yang melakukan tindak pidana eksploitasi seksual terhadap anak diancam dengan pidana paling lama 10 tahun dan/atau denda paling banyak sebesar 200 juta rupiah. ${ }^{40}$ Selain dalam UU Perlindungan Anak, UU No. 44 Tahun 2008 tentang Pornografi (UU Pornografi) juga turut membahas mengenai perlindungan anak. Pasal 38 UU Pornografi mengatur ancaman pidana bagi orang yang mengajak, membujuk, memanfaatkan, membiarkan, menyalahgunakan kekuasaan atau memaksa anak dalam menggunakan produk atau jasa pornografi dengan pidana penjara paling

\footnotetext{
${ }^{37}$ Lihat Pasal 67A, 68, dan 69A UU No. 35 Tahun 2014 tentang Perubahan atas UU No. 23 Tahun 2002 tentang Perlindungan Anak.

38 Lihat Pasal 81 Perpu No. 1 Tahun 2016 tentang Perubahan Kedua UU Perlindungan Anak.

39 Lihat Pasal 82 Perpu No. 1 Tahun 2016 tentang Perubahan Kedua UU Perlindungan Anak.

40 Lihat Pasal 88 UU No. 35 Tahun 2014 tentang Perubahan atas UU No. 23 Tahun 2002 tentang Perlindungan Anak.
} 
singkat 6 bulan dan paling lama 6 tahun dan/atau pidana denda paling sedikit 250 juta rupiah dan paling besar 3 miliar rupiah

\section{KESIMPULAN DAN REKOMENDASI}

\section{Kesimpulan}

Penulis menyimpulkan dua kesimpulan dalam penulisan ini. Pertama, anak didefinisikan sebagai setiap orang yang berusia di bawah 18 tahun termasuk yang masih dalam kandungan dan tidak dianggap sebaliknya menurut peraturan perundang-undangan. Anak termasuk golongan kelompok rentan karena secara alamiah sangat bergantung pada orang dewasa dan belum memiliki otonomi penuh dalam melakukan tindakan tertentu layaknya orang dewasa. Dalam kondisi pandemi COVID-19, terdapat studi yang menemukan bahwa penggunaan teknologi digital dan internet meningkat, tidak terlepas dari pengguna anak-anak. Penggunaan internet oleh anak juga meningkat sebab pembelajaran dilakukan jarak jauh melalui teleconference dan video. Oleh karena itu, anak menjadi rentan terhadap kekerasan seksual online akibat tingginya paparan internet diiringi dengan minimnya pengawasan orang tua.

Kedua, hak atas anak diatur dalam CRC yang telah diratifikasi oleh Indonesia melalui Keppres No. 36 Tahun 1990. Selain melalui ratifikasi CRC, pemerintah membentuk UU Perlindungan Anak yang melindungi hak-hak anak dan kerentanan anak terhadap tindak pidana tertentu, termasuk kekerasan seksual meskipun tidak secara eksplisit menyebutkan kekerasan seksual online. Kekerasan seksual online terhadap anak antara lain eksploitasi seksual, pornografi, perdagangan anak, dan kejahatan seksual. Kekerasan seksual terhadap anak diatur dalam UU No. 17 Tahun tentang Penetapan Perppu No. 1 Tahun 2016, UU No. 35 Tahun 2014, UU No. 23 Tahun 2002, dan khusus untuk pornografi diatur dalam UU No. 44 Tahun 2008 tentang Pornografi. Dalam UndangUndang tersebut, kejahatan seksual online tidak eksplisit dibahas namun perlu dipahami bahwa tindakan berupa kekerasan seksual online juga dilakukan secara langsung.

\section{Rekomendasi}

Selama pandemi COVID-19, kekerasan seksual online terhadap anak meningkat, sehingga diperlukan tindakan seluruh lapisan masyarakat secara terintegrasi. Pemerintah, pemerintah daerah, lembaga negara lainnya, keluarga dan orang tua, serta masyarakat berkewajiban melindungi hak anak. Keluarga dan orang tua dapat mencegah kekerasan seksual online terhadap anak dengan melakukan penapisan di internet, restriski konten negatif di internet, dan proaktif melaporkan konten negatif kepada Kemenkominfo.

Dalam konteks pengaturan dan perlindungan hukum, pemerintah sudah melakukan upaya-upaya seperti meratifikasi CRC dan Optional Protocol yang berkaitan dengan hal tersebut dan membentuk peraturan perundang-undangan yang melindungi anak. Alangkah baiknya jika pemerintah dapat memperkuat penegakkan hukum sesuai peraturan perundang-undangan demi terjaminnya perlindungan atas hak anak dari kekerasan seksual online sebagai salah satu kelompok yang tergolong rentan 


\section{DAFTAR PUSTAKA}

Buku

Raco, J. R. 2010. Metode Penelitian Kualitatif: Jenis, Karakteristik dan Keunggulannya. Jakarta: Grasindo.

Soekanto, S. 2014. Pengantar Penelitian Hukum. Jakarta: Universitas Indonesia (UI-Press).

Soekanto, S., \& Mamudji, S. 1994. Penelitian Hukum Normatif: Suatu Tinjauan Singkat. Jakarta: Raja Grafindo Persada.

\section{Buku dari Internet}

Runyan, D., Hassan, F., \& May-Chahal, C. 2002. Child Abuse and Neglect by Parents and Other Caregivers (From World Report on Violence and Health). Geneva: World Health Organization. $\quad$ Retrieved April 1, 2021, from https://www.who.int/violence_injury_prevention/violence/global_campaign/en/chap3.pdf.

Sofian, A., Pratama, B., Ramadani, D., \& Banyumurti, I. 2018. Modul Pelatihan Pencegahan Eksploitasi Seksual Anak Online untuk Organisasi Perlindungan Anak dan Komunitas. Jakarta: P. ECPAT Indonesia. Retrieved April 3, 2021, from http://eksis.ditpsmk.net/uploads/book/file/186F5A7E-E5E5-416C-9B00-

A7BB88101526/moduleksploitasifinal-180207071018.pdf.

United Nations Children's Fund. 2020. Action to End Child Sexual Abuse and Exploitation. New York: UNICEF Child Protection Section Programme Division 3 United Nations Plaza New York. Retrieved April 3, 2021 from https://www.unicef.org/media/89206/file/CSAE-Briefv3.pdf.

Jurnal

Association of Southeast Asian Nations. 2020. Economic Impact of COVID-19 Outbreak on ASEAN. Asean Policy Brief.

Jurnal dengan DOI

Bagattini, A. 2019. Children's Well-being and Vulnerability. Ethics and Social Welfare, 13(3), 211-215. doi:10.1080/17496535.2019.1647973

Fana, M., Torrejón Pérez, S., \& Fernández-Macías, E. 2020. Employment Impact of Covid-19 Crisis: From Short Term Effects to Long Terms Prospects. Journal of Industrial and Business Economics, 47(3), 391-410. doi:10.1007/s40812-020-00168-5

Paul, A., Nath, K., Mahanta, J., Sultana, N. N., Kayes, A. I., Noon, S. J., . . . Paul, S. 2021. Psychological and Livelihood Impacts of COVID-19 on Bangladeshi Lower Income People. Asia Pacific Journal of Public Health, 33(1). doi:DOI: https://doi.org/10.1177/1010539520977304

Dokumen dari Internet

The Alliance for Child Protection in Humanitarian Action, End Violence Against Children, United Nations Children's Fund, \& World Health Organization. (n.d.). COVID-19: Protecting 
Children from Violence, Abuse and Neglect in the Home. Retrieved April 1, 2021, from https://www.unicef.org/media/68711/file/COVID-19-Protecting-children-from-violenceabuse-and-neglect

Chan, C. (n.d.). How COVID-19 is Accelerating Indonesia's Digital Transformation. Retrieved March 31, 2021, from https://digital.australiaindonesiacentre.org/news/insights/commentary/how-covid-19-isaccelerating-indonesias-digital-transformation/

Presidential Commission for the Study of Bioethical Issues. (n.d.). Vulnerable Populations: Safeguarding Children. Retrieved April 3, 2021, from https://bioethicsarchive.georgetown.edu/pcsbi/sites/default/files/6\%20Vulnerable\%20Popu lations\%20Safeguarding\%20Children\%209.30.16.pdf

World Health Organization. (March). Coronavirus disease 2019 (COVID-19) Situation Report 94. Retrieved March 26, 2021, from https:/www.who.int/docs/defaultsource/coronaviruse/situation-reports/20200423-sitrep-94-covid-19.pdf

World Health Organization. (n.d.). Violence Injury Prevention. Retrieved April 1, 2021, from https://www.who.int/violence_injury_prevention/resources/publications/en/guidelines_cha p7.pdf

\section{Berita dari Internet}

Halidi, R. 2020. Selama Pandemi Corona, Hampir 2 Ribu Anak Indonesia Alami KEKERASAN SEKSUAL. $\quad$ Retrieved March 31, 2021, from https://www.suara.com/health/2020/07/08/083741/selama-pandemi-corona-hampir-2-ribuanak-indonesia-alami-kekerasan-seksual?page=all

Kekerasan Seksual Anak Online Meningkat di Masa Pandemi COVID-19. (2020, August 02). Retrieved April 03, 2021, from https://ecpatindonesia.org/en/berita/kekerasan-seksual-anakonline-meningkat-di-masa-pandemi-covid-19/

Nuraini, R. (n.d.). Kasus Covid-19 Pertama, Masyarakat Jangan Panik. Retrieved March 29, 2021, from https://indonesia.go.id/narasi/indonesia-dalam-angka/ekonomi/kasus-covid-19pertama-masyarakat-jangan-panik

\section{Peraturan Perundang-Undangan}

Keputusan Presiden No. 36 Tahun 1990 tentang Pengesahan Convention on the Rights of the Child. Peraturan Pemerintah Pengganti Undang-Undang No. 1 Tahun 2016 tentang Perubahan Kedua atas Undang-Undang No. 23 Tahun 2002 tentang Perlindungan Anak.

Undang-Undang No. 10 Tahun 2012 tentang Pengesahan Optional Protocol to the Convention on the Rights of the Child on the Sale of Children, Child Prostitution and Child Pornography.

Undang-Undang No. 17 Tahun 2016 tentang Penetapan Peraturan Pemerintah Pengganti UndangUndang No. 1 Tahun 2016 tentang Perubahan Kedua atas Undang-Undang No. 23 Tahun 2002 tentang Perlindungan Anak.

Undang-Undang No. 23 Tahun 2002 tentang Perlindungan Anak. 
Kerentanan Anak Indonesia terhadap Kekerasan Seksual....

Undang-Undang No. 35 Tahun 2014 tentang Perubahan atas Undang-Undang No. 23 Tahun 2002 tentang Perlindungan Anak.

Undang-Undang No. 44 Tahun 2008 tentang Pornografi.

Konvensi Internasional

Convention on the Rights of the Child 